\title{
3D Printed Hydrogel Multiassay Platforms for Robust Generation of Engineered Contractile Tissues
}

Christensen, Rie Kjær; von Halling Laier, Christoffer; Kiziltay, Aysel; Wilson, Sandra; Larsen, Niels Bent

Published in:

Biomacromolecules

Link to article, DOI:

10.1021/acs.biomac.9b01274

Publication date:

2020

Document Version

Peer reviewed version

Link back to DTU Orbit

Citation (APA):

Christensen, R. K., von Halling Laier, C., Kiziltay, A., Wilson, S., \& Larsen, N. B. (2020). 3D Printed Hydrogel

Multiassay Platforms for Robust Generation of Engineered Contractile Tissues. Biomacromolecules, 21(2), 356365. https://doi.org/10.1021/acs.biomac.9b01274

\section{General rights}

Copyright and moral rights for the publications made accessible in the public portal are retained by the authors and/or other copyright owners and it is a condition of accessing publications that users recognise and abide by the legal requirements associated with these rights.

- Users may download and print one copy of any publication from the public portal for the purpose of private study or research.

- You may not further distribute the material or use it for any profit-making activity or commercial gain

- You may freely distribute the URL identifying the publication in the public portal 


\section{3D printed hydrogel multi assay platforms for robust}

\section{2 generation of engineered contractile tissues}

3 Rie Kjar Christensen ${ }^{1,2}$, Christoffer von Halling Laier ${ }^{1}$, Aysel Kiziltay ${ }^{1 \dagger}$, Sandra Wilson ${ }^{2}$, Niels

4 Bent Larsen ${ }^{l *}$.

$5 \quad{ }^{1}$ Department of Health Technology, DTU Health Tech, Technical University of Denmark,

6 Ørsteds Plads 345C, 2800 Kgs. Lyngby, Denmark. ${ }^{2}$ Sophion Bioscience A/S, Baltorpvej 154,

72750 Ballerup, Denmark.

8 AUTHOR INFORMATION

9 Corresponding Author

10 *E-mail: nibl@dtu.dk. Fax: +45 4588 7762. Tel.: +45 45258161.

\section{Present Addresses}

$12 \uparrow$ Central Laboratory, Middle East Technical University (METU), Ankara, Turkey.

\section{Author Contributions}

14 The manuscript was written through contributions of all authors. All authors have given approval 15 to the final version of the manuscript. 
We present a method for reproducible manufacture of multi assay platforms with tunable mechanical properties for muscle tissue strip analysis. The platforms result from stereolithographic 3D printing of low protein-binding poly(ethylene glycol) diacrylate (PEGDA) hydrogels.

21 Contractile microtissues have previously been engineered by immobilizing suspended cells in a confined hydrogel matrix with embedded anchoring cantilevers to facilitate muscle tissue strip formation. The 3D shape and mechanical properties of the confinement and the embedded cantilevers are critical for the tissue robustness. High-resolution 3D printing of PEGDA hydrogels offers full design freedom to engineer cantilever stiffness while minimizing unwanted cell attachment. We demonstrate the applicability by generating suspended muscle tissue strips from $\mathrm{C} 2 \mathrm{C} 12$ mouse myoblasts in a compliant fibrin-based hydrogel matrix. The full design freedom allows for new platform geometries that reduce local stress in the matrix and tissue, thus reducing the risk of tissue fracture.

KEYWORDS Microtissue engineering; PEGDA; Hydrogel; Stereolithography; Fibrin; Matrigel;

Hydrogel materials made from biological or synthetic macromolecules are widely applied in the life science area, including in analytics and advanced cell culture. Hydrogels offer tunable protein and cell adhesion properties, widely variable mechanical properties, and controllable diffusivity of dissolved compounds. Hydrogel materials have traditionally been cast into their targeted final 
3D shape, which limits the attainable design freedom. The recent emergence of $3 \mathrm{D}$ printing methods enables direct and fast manufacture of highly complex 3D shapes. Major 3D printing methods for hydrogels include mechanical extrusion of polymer solutions (including cell-laden hydrogels used in bioprinting $)^{1}$ and spatially selective photochemical cross-linking (stereolithography) ${ }^{2}$ of macromolecules.

Engineering of miniaturized tissue-like 3D cell aggregates, for example contractile muscle tissue strips, is a key application of hydrogel 3D printing. Here, we explore the use of high-resolution stereolithographic 3D printing of a synthetic polymer - poly(ethylene glycol) diacrylate (PEGDA) - into a force sensing and cell seeding hydrogel unit supporting the formation of contractile microtissues from a suspension of muscle cells in a biological polymer hydrogel (fibrinogen/Matrigel). Free-form 3D microshaping of the synthetic hydrogel parts enables broad tuning of the force responsiveness as well as guidance of the microtissue formed into a welldefined 3D shape with low residual stress. The combination of a low cell-adherent 3D printed PEGDA hydrogel mold and a high cell-adherent fibrin hydrogel as cell matrix supports the robust formation of stable contractile microtissues needed for their applications, for example in drug development and safety screening. Our previous work on photochemically anchored poly(ethylene glycol) $(\mathrm{PEG})^{3}$ and $\mathrm{PEGDA}^{4}$ hydrogel coatings demonstrated their ability to limit non-specific adsorption of proteins, DNA, and small lipophilic drug molecules, which is essential for their use in drug testing devices. This is a significant advantage over previously published device solutions ${ }^{5-9}$ using poly(dimethyl siloxane) (PDMS) that is known to absorb and deplete dissolved lipophilic compounds. ${ }^{10}$

Engineered muscle tissue strips (MTS) are of broad interest in application areas such as drug screening, individualized medicine, disease modelling, and tissue grafts. As a result, methods to 
61 obtain a mature and robust muscle tissue have been explored during the last decade. ${ }^{11-19}$ A shift in tissue culture platform design from 2D cantilevers with adherent cells ${ }^{20-22}$ towards free hanging tissues between cantilever beams has been pursued as this $3 \mathrm{D}$ conformation seems to have a positive effect in both tissue formation and maturation. ${ }^{23-26}$ Producing a physiologically relevant 3D environment will promote cell differentiation and tissue formation compared to standard 2D or matrix encapsulation as it mechanically directs the cells to elongate and form better cell-cell connections..$^{5,27-30}$

A main challenge in contractile microtissue engineering is the robustness of the constructed tissues against 'necking' behavior leading to subsequent failure. ${ }^{31}$ Previous studies have shown the importance of cantilever stiffness and matrix composition on the robustness of the engineered tissue..$^{24,31-33}$ However, the effects of geometrical features of the cantilever itself have not been extensively studied, likely due to the limited 3D design freedom of conventional molding approaches. Here, we present a fast method for producing tissue formation platforms using synthetic PEGDA hydrogels to generate muscle microtissues. We employ a custom-built stereolithographic 3D printer to reproducibly manufacture tissue culturing platforms with microstructures for optical tracking and for promotion of tissue formation in designs that cannot be obtained by conventional molding or $3 \mathrm{D}$ printing methods. This allows for a broader design spectrum and gives the possibility to further explore the mechanically induced tissuedifferentiation possibilities. The introduction of optical markers further enables accurate contraction analysis valuable in upscaling for industrial use.

\section{Stereolithographic 3D Printing and Printing Solution Composition.}



Sigma-Aldrich) hydrogels are obtained by projection stereolithography using a previously described custom-built high resolution 3D printer. $^{2}$ The printer uses one-to-one projection of dynamic images displayed on a Digital Mirror Device (DMD) with a pixel pitch of $10.8 \mu \mathrm{m}$ in both lateral dimensions. The aqueous printing solutions contain $5 \mathrm{mg} / \mathrm{mL}$ photoinitiator (lithium phenyl-2,4,6-trimethylbenzoylphosphinate, LAP, Allevi or 900889, Sigma-Aldrich) and $9 \mathrm{mg} / \mathrm{mL}$ photoabsorber (quinoline yellow, QY, 309052, Sigma-Aldrich) dissolved in ultrapure MilliQ water (MQ, Merck-Millipore) with either $200 \mathrm{mg} / \mathrm{mL}$ PEGDA ('20\% PEGDA') or $500 \mathrm{mg} / \mathrm{mL}$ PEGDA ('50\% PEGDA'). The solution components are mixed at room temperature and degassed for 30 min to avoid bubbles that would interfere with the initiator light and cause deformations in the $3 \mathrm{D}$ printed object.

Computer aided design (CAD) structures are drawn using Autodesk Inventor Professional with dimensions fitting a multiple of the pixel pitch $(10.8 \mu \mathrm{m})$ of the printer's DMD. This secures the best possible dimension accuracy of the printed subject compared to the CAD design dimensions. The CAD structure is sliced with a thickness of $20 \mu \mathrm{m}$ using the open source Slic3r software (www.slic3r.org). The sliced structure is 3D printed with $365 \mathrm{~nm}$ light with an intensity of 20 $\mathrm{mW} / \mathrm{cm}^{2}$ using $3 \mathrm{~s}$ or $5 \mathrm{~s}$ of light exposure for 50\% PEGDA and 20\% PEGDA, respectively. The structure is $3 \mathrm{D}$ printed on a surface treated glass cover slip $(22 \times 22 \mathrm{~mm} \# 4$, Menzel-Gläser $)$. The surface treatment provides a methacrylate layer on the cover slip to enable chemical crosslinking between the print and the glass cover slide. ${ }^{2}$

\section{Analysis of the Relative Degree of Swelling and Dimensional Change.}


The dimensional stability of the 3D printed materials is assessed by measuring the timedependent swelling of printed circular PEGDA cylinders immersed in water and by microscopy analysis of rectangular PEGDA blocks having rectangular indentations or protrusions at their surface. Circular cylinders of diameter $6 \mathrm{~mm}$ and height $5 \mathrm{~mm}$ are printed in 20\% PEGDA and $50 \%$ PEGDA. The printed cylinders are weighed immediately after printing. The cylinders are then placed in MQ water and weighed every hour for $6 \mathrm{~h}$. The MQ water is exchanged twice and cylinders are left in MQ water for a total of $16 \mathrm{~h}$ before the weight is determined again. Cylinders are dried at $60{ }^{\circ} \mathrm{C}$ for $8 \mathrm{~h}$ and the weight is monitored every second hour to obtain the stable dry weight. The equilibrium volumetric swelling ratio, $Q$, is determined for 5 cylinders of $20 \%$ PEGDA and of 50\% PEGDA using Eq. (1), where $V$ is volume, $\rho$ is mass density, $q=m_{s} / m_{d}$ is the equilibrium mass swelling ratio, and $m$ is the mass. Subscripts $s$ and $d$ indicate the swollen and dry polymer respectively, while $\rho_{\text {pol }}$ and $\rho_{\text {sol }}$ are the polymer and solvent mass densities.

$$
Q=1+\frac{\rho_{p o l}}{\rho_{\text {sol }}}(q-1)=\frac{V_{s}}{V_{d}}
$$

The dimensional change after swelling is determined by printing $4 \times 5 \times 1 \mathrm{~mm}^{3}$ blocks of $20 \%$ PEGDA and 50\% PEGDA having rectangular surface indentations and protrusions with widths of $108 \mu \mathrm{m}$ to $324 \mu \mathrm{m}$ and a 1:3 width to length aspect ratios. The widths are designed to be multiples of the DMD's $10.8 \mu \mathrm{m}$ pixel pitch to achieve the highest possible spatial resolution. The depths of indentations and heights of protrusions are $100 \mu \mathrm{m}$ for all surface features. The samples are imaged by microscopy immediately after printing and after equilibrium swelling in MQ water. The dimensions of the structures are determined using the FIJI/imageJ software package. ${ }^{34}$

\section{Compression Modulus Analysis.}


130 PEGDA and left in MQ water overnight to reach their equilibrium swelling ratio. The dimensions

131 of the swollen cylinders are determined, and the shear modulus is measured in a uniaxial 132 compression test using an Instron 5967 (Instron, MA). Samples are placed wet between two 133 parallel plates and compressed at a rate of $0.5 \mathrm{~mm} / \mathrm{min}$ at room temperature until sample failure.

134 The shear modulus $(G)$ is determined by plotting the engineering stress $(\sigma)$ against the $\lambda-\lambda^{-2}$ ratio 135 according to Eq. (2), where $\lambda$ is the extension ratio. Linear regression is performed in the linear 136 region of $\lambda-\lambda^{-2}$ (0.2 to 0.6 for $50 \%$ PEGDA and 0.2 to 0.8 for $20 \%$ PEGDA) to determine $G{ }^{35}$

$$
\sigma=G\left(\lambda-\frac{1}{\lambda^{2}}\right)
$$

\section{Cantilever Stiffness Analysis.}

140 Cantilevers of designed length $850 \mu \mathrm{m}$ and diameters of $100 \mu \mathrm{m}, 200 \mu \mathrm{m}$ and $300 \mu \mathrm{m}$ are printed 141 in 20\% PEGDA and in 50\% PEGDA. The printed cantilevers are placed horizontally in an aqueous

142 environment with one end at a fixed height on a scale. A piezoelectric actuator is used to displace 143 the free end of the cantilever vertically by $220 \mu \mathrm{m}$ (Electronic Supporting Information, Figure S1).

144 The measured weight increase on the scale is used to calculate the actuation force. The stiffness, $145 k$, is determined using Eq. (3) derived from the Euler-Bernoulli beam theory. $F, E$ and $I$ are the 146 force, Young's modulus, and moment of inertia, respectively. $L, x$, and $\delta$ denote the length of the 147 cantilever, distance from the fixed end to the point of force application, and the vertical 148 displacement, respectively.

$$
F=k \cdot \delta=\frac{6 E I}{3 L x^{2}-x^{3}} \delta
$$

150 The moment of inertia for a circular cylinder is given by Eq. (4) where $d$ is the cylinder diameter. 


$$
I=\frac{\pi d^{4}}{64}
$$

152 Five independent samples are analyzed for each condition, except for $100 \mu \mathrm{m}$ diameter

153 cantilevers in 20\% PEGDA where only 3 samples are analyzed due to inconsistent printing.

\section{Preparation of MicroArray Platforms.}

Three different MicroArray Platforms (MAP) are produced for generating Muscle Tissue Strips

157 (MTS). Two designs are selected from previously investigated cell seeding platforms with the use saline (PBS) for at least $24 \mathrm{~h}$ after printing. The liquid is exchanged two times to wash out any residual print solution from the cross-linked PEGDA network. Sterilization is performed by immersing the printed MAPs in 70\% v/v ethanol/water for 10 minutes followed by UV-C exposure

$164(254 \mathrm{~nm})$ for 15 minutes (Mini UV Sterilisation Cabinet, Cleaver Scientific). The MAPs are stored

165 sterile in PBS until use to ensure exchange of water to PBS prior to cell culture. Before seeding

166 cells into the MAPs, the PBS is removed and the platforms are blotted dry with sterile lint free

167 paper to make sure the wells are empty.

\section{Cell Seeding and Cell Culture.}

$170 \mathrm{C} 2 \mathrm{C} 12$ mouse myoblasts (C3H muscle myoblast, 91031101, Sigma-Aldrich) are used at passage

1715 to 8 . Cells are kept in culture using growth medium composed of DMEM high glucose (Sigma172 Aldrich) with 10\% fetal bovine serum (FBS) (Sigma-Aldrich), and 1\% Penicillin/Streptomyocin

173 (P/S, Sigma-Aldrich). Tissue formation is initiated by casting cells suspended at $10 \times 10^{6}$ cells $/ \mathrm{mL}$ 
in a solution of $10 \mathrm{mg} / \mathrm{mL}$ fibrinogen (F8630, Sigma-Aldrich), $0.5 \mu \mathrm{g} / \mathrm{mL}$ aprotinin (A1153,

175 Sigma-Aldrich), 20\% (v/v) Matrigel (354277, Corning), and 3 U/mL thrombin (T7513, Sigma-

176 Aldrich) in growth medium into the prepared MAPs. The solution is kept on ice to prevent gelation

177 until casting. The larger MAP wells ('MINIMAP', Figure 1b; 'LOWSTRESSMAP', Figure 1c)

178 are filled individually with $3.5 \mu \mathrm{L}$ of the cell suspension. The smaller MAP wells ('MICROMAP',

179 Figure 1a) are filled in a two step process. First, $200 \mu \mathrm{L}$ of cell suspension is loaded on top of all

180 wells of the MAP. Second, the MAP is spun in a centrifuge at $200 \mathrm{~g}$ for $10 \mathrm{~s}$ to force the suspension

181 into the wells, similar to the process used in the work by Legant et al. ${ }^{24}$

182 The loaded MAPs are incubated at $37^{\circ} \mathrm{C}$ for $30 \mathrm{~min}$ to let the fibrin matrix form before growth

183 medium is added. After 2 days in culture, the medium is changed to DMEM high glucose with $2 \%$

184 FBS and $1 \% \mathrm{P} / \mathrm{S}$ to enhance the fusion of myoblasts to myotubes. ${ }^{36}$ Medium change is conducted

185 every 2-3 days throughout the culture time.

186 Optical tracking of tissue formation.

187 The wells of a LOWSTRESSMAP printed in 50\% PEGDA and with a cantilever diameter of $188100 \mu \mathrm{m}$ are imaged from day 1 after seeding until full tissue formation. Tissue contraction is 189 monitored using a custom made stage incubator mounted on a Motic stereomicroscope. Images 190 are recorded every 5 min. A custom made tracking software is used to track the optical markers on 191 the cantilever tops in the acquired image sequences.

\section{Viability Staining.}

193 Staining is performed by incubating for $1 \mathrm{~h}$ at $37^{\circ} \mathrm{C}$ with $2 \mu \mathrm{g} / \mu \mathrm{L}$ Calcein AM (15560597,

194 Fisher Scientific), $4 \mu \mathrm{g} / \mathrm{mL}$ propidium iodide (81845, Sigma-Aldrich), and $2 \mu \mathrm{g} / \mathrm{mL}$ Hoechst 19534580 (H21486, Invitrogen). Samples are then washed with medium before confocal imaging on 196 a Zeiss LSM700 using a Zeiss 10x/0.3NA Epiplan Neofluar objective with excitation at 405, 488, 
and $555 \mathrm{~nm}$ for Hoechst 34580, calcein AM, and propidium iodide, respectively. The recorded zstacks are collapsed to a 2D image in FIJI/ImageJ by maximum intensity projection.

\section{Cryopreservation and Immunohistochemistry.}

Cell-laden MAPs are fixated in 4\% paraformaldehyde (PFA) for 30 min, washed in PBS and cryo protected by incubation at room temperature in a $10 \mathrm{mg} / \mathrm{mL}$ solution of poly(ethylene glycol) $M \mathrm{n} 10 \mathrm{~kg} \cdot \mathrm{mol}^{-1}$ (PEG10k, 92897, Sigma-Aldrich) for 6-8 $\mathrm{h}$ followed by incubation in $100 \mathrm{mg} / \mathrm{mL}$ PEG10k overnight at $4{ }^{\circ} \mathrm{C}$. The samples are gently dried to remove excess PEG10k and transferred into embedding medium (Tissue-Tek OCT Compound, Leica) before being snap-frozen on isopentane chilled on liquid nitrogen and stored at $-80{ }^{\circ} \mathrm{C}$. For immunohistochemistry, $10 \mu \mathrm{m}$ to $20 \mu \mathrm{m}$ thick sections are cut at $-25{ }^{\circ} \mathrm{C}$ using a cryo microtome (Leica 3050 ) and dried.

For $\alpha$-actinin labeling, cryo sections on glass slides are first washed with PBS to remove excess OCT and then permeabilized in $0.2 \%$ Triton X-100 for 5 min and blocked in blocking buffer (2\% $\mathrm{w} / \mathrm{v}$ BSA and $5 \% \mathrm{v} / \mathrm{v}$ horse serum in PBS) for $1 \mathrm{~h}$ at room temperature (RT). The sections are then incubated for $2 \mathrm{~h}$ at RT in blocking buffer with 1:200 monoclonal anti- $\alpha$-actinin (sarcomeric) IgG produced in mouse (A7811, Sigma-Aldrich). They are subsequently washed twice with PBS and incubated for $2 \mathrm{~h}$ at RT in the dark with $2 \mu \mathrm{g} / \mathrm{mL}$ polyclonal FITC-conjugated goat F(ab')2 antimouse IgG $(\mathrm{H}+\mathrm{L})(\mathrm{SAB} 4600388$, Sigma Aldrich) in blocking buffer. Afterwards, sections are stained with $2 \mu \mathrm{g} / \mathrm{mL}$ Hoechst 34580 for $15 \mathrm{~min}$ and washed 3 times with PBS. The sections are imaged with a Nikon Ti2/Yokogawa CSU-W1 spinning disc confocal microscope using a Nikon Plan Apo $\lambda$ 20x/0.75 NA objective with excitation at 405 and $488 \mathrm{~nm}$ for Hoechst 34580 and FITC, respectively. The resulting image stacks are processed using FIJI/ImageJ. 
RESULTS AND DISCUSSION

\section{Design and Manufacture of Multi Assay Platforms (MAPs).}

222 Controlling the cellular orientation and the mechanical environment are key factors to achieve 223 better and more robust translation from single cells to tissue. Various MAP designs using similar 224 design concepts have been reported over the last decade. ${ }^{24,26,13,25}$ All have shown aligned growth 225 of contractile cells, including fibroblasts, myotubes, and cardiomyocytes. ${ }^{37}$ However, previous reports mostly use low throughput manufacturing methods. The authors also observe tissue damage and failure due to high internal stresses in the formed tissues. Most research has employed rectangular cantilevers that are likely to induce large tensile stress in the seeded cell-laden matrix hydrogel during initial hydrogel compaction and subsequent tissue formation. The stress is predicted to be maximum along the center line of the microtissue suspended between the cantilevers. ${ }^{31}$ The full design freedom offered by stereolithographic 3D printing can be exploited to integrate tissue guide structures that reduces the intermittent and final stress. Another key design aspect is the microtissue size, with smaller sizes needing fewer cells per tissue but also likely

234 complicating the seeding procedure due to the tiny matrix volumes used. Large tissues are easier 235 to handle but may suffer from core cell death and propensity for tissue failure due to insufficient 236 oxygen and nutrient diffusion to the tissue core. We investigate both design parameters by using 237 stereolithographic 3D printing of PEGDA to functionally reproduce two formerly published rectangular PDMS cantilever designs of different sizes as baseline for evaluating a new design overcoming the residual stress limitations of the rectangular cantilever format. 
a)

b)

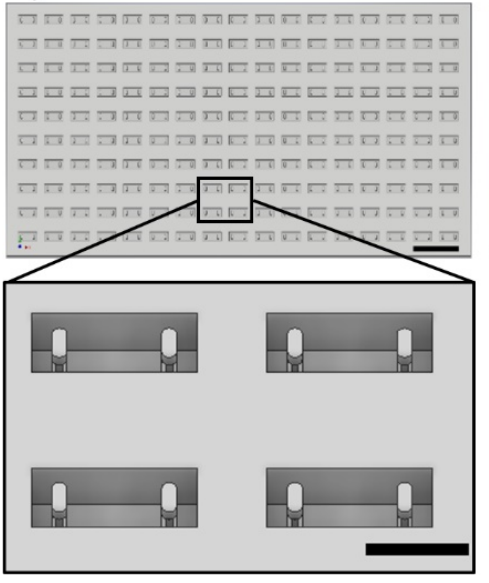

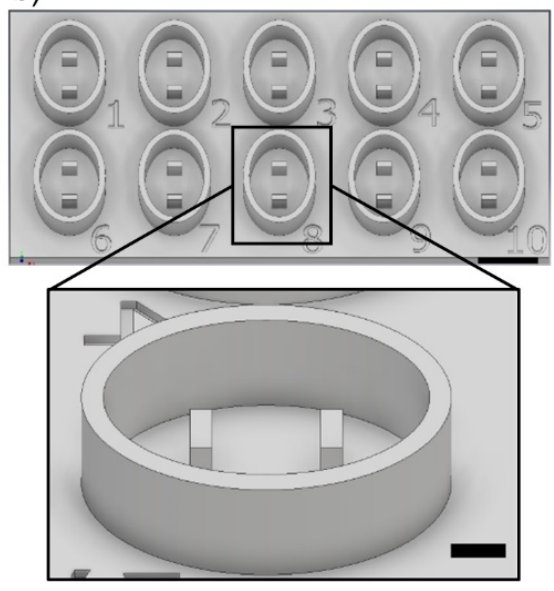

c)

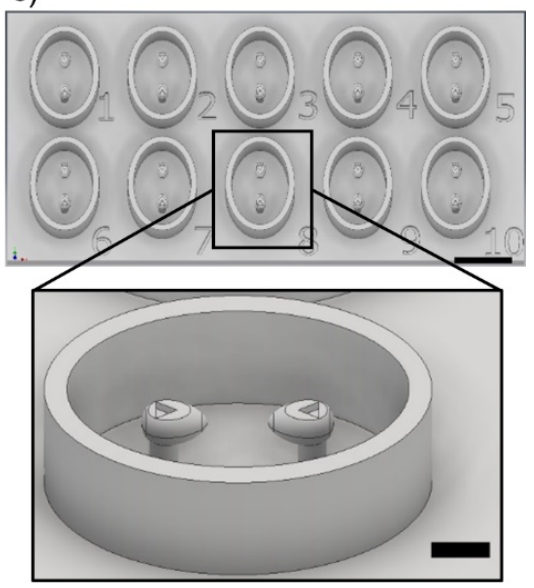

Figure 1. Multi Assay Platform (MAP) designs containing wells with integrated cantilevers for tissue formation. (a) Micro-well MAP (MICROMAP) with 170 micro wells using rectangular cantilevers. (b) Mini-well MAP (MINIMAP) with 10 mini-wells using rectangular cantilevers. (c) Low residual Stress MAP (LOWSTRESSMAP) with 10 mini-wells using circular cantilevers with a cantilever end engineered to minimize local stress in the forming muscle microtissue. The LOWSTRESSMAP design additionally includes a 3D triangular micromarker at the cantilever end to facilitate automated optical tracking of the cantilever end displacement. Scale bars $2 \mathrm{~mm}$ (top row) and $500 \mu \mathrm{m}$ (bottom row).

One design reported by Legant et al. ${ }^{24}$ uses microsized cantilevers and tissues ('MICROMAP') (Figure 1a), while the other design reported by Mills et al. ${ }^{25}$ employs mesosized cantilevers and tissues ('MINIMAP') (Figure 1b). Both MAP designs have showed successful tissue formation using contractile cells. We also introduce a new MAP format, LOWSTRESSMAP, designed to lower the stress concentrations in the formed tissues around the edges of the cantilever end (Figure 1c). A droplet shaped enlargement with soft edges to reduce local stresses (referred to as 'biomechanical cue') is added at the top of a cylindrical cantilever to guide the location of the tissue formed. It is shaped with rounded edges to reduce stress concentrations and secure the tissue 
257 from slipping off the cantilevers. Printing times are $8 \mathrm{~min}$ for the 170-well MICROMAP design 258 and 17 min for the 10-well MINIMAP and LOWSTRESSMAP designs. All MAPs are fabricated 259 in PEGDA having low protein-binding surface properties to prevent unwanted cell attachment. 260 The material properties of cross-linked PEGDA vary greatly with the concentration of the printing 261 solution components and with the exposure time. Solution composition and exposure times are 262 chosen to provide robust and reproducible manufacturing of the chosen cantilever designs.

Mechanical Characterization of 3D Printed PEGDA Hydrogels.

266 The shear modulus of hydrogels printed using 20\% PEGDA and 50\% PEGDA is determined by 267 a uniaxial compression test. Increasing the PEGDA concentration from $20 \%$ to $50 \%$ results in 268 nearly an 8-fold increase in shear modulus from $0.47 \pm 0.046 \mathrm{MPa}$ to $3.6 \pm 0.46 \mathrm{MPa}$. The denser 269 network formed at the higher PEGDA concentration results in a more brittle platform, which 270 makes it more susceptible to notching and subsequent failure during handling. The lower PEGDA 271 concentration is consequently preferred to create a more flexible and stable $\mathrm{MAP}^{38}$ in the handling 272 process during cell seeding and analysis. 
a)

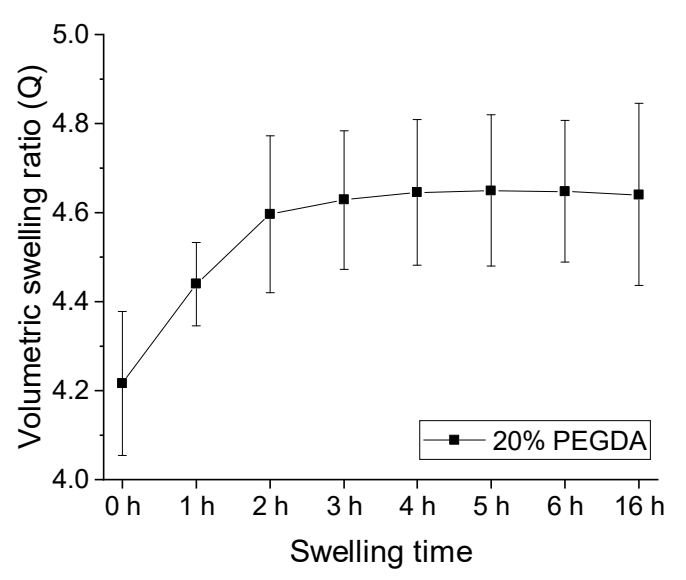

b)

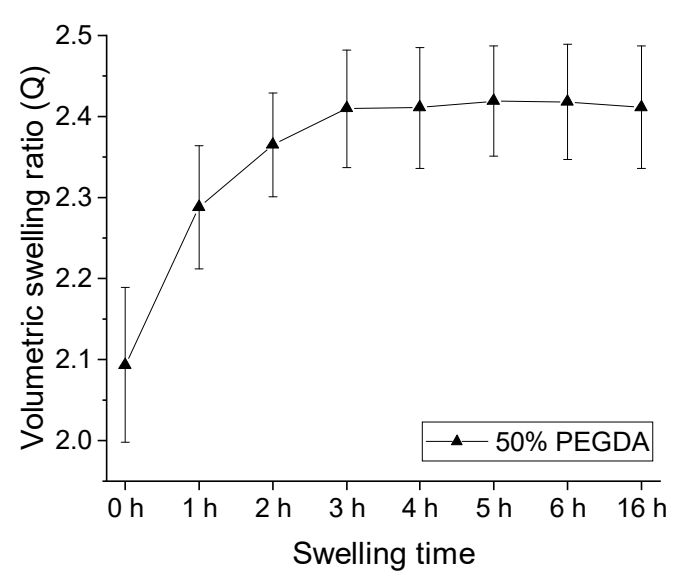

274 Figure 2. Mean volumetric swelling ratio of (a) 20\% PEGDA and (b) 50\% PEGDA measured on $2755 \mathrm{~mm}$ high and $6 \mathrm{~mm}$ diameter cylinders immersed in MQ water after printing. Cylinders incubated 276 for $16 \mathrm{~h}$ are dried for $8 \mathrm{~h}$ at $60{ }^{\circ} \mathrm{C}$ before measuring the dry polymer mass. Error bars show the 277 standard deviation $(\mathrm{n}=5)$.

279 Dimensional Stability of 3D printed PEGDA Hydrogels.

280 MAP design features are carefully selected to give a robust platform with visible markers and 281 robust structures. Reliable dimensions are therefore essential to MAP characteristics. PEGDA has 282 a higher affinity for water than for itself and will swell after printing, when transferred from the 
printing solution to pure water. ${ }^{39}$ The equilibrium volumetric swelling ratio, $Q$, is reached after 3

$284 \mathrm{~h}$ for 3D printed objects in 20\% PEGDA and in 50\% PEGDA immersed in MQ water at room temperature (Figure 2). The relative volumetric increase from pristine print to equilibrium swelling is $15.3 \%$ for $50 \%$ PEGDA and $9.2 \%$ for $20 \%$ PEGDA. The swelling ratio is higher at lower PEGDA concentration due to a higher initial water content in the samples. However, the relative volumetric swelling from pristine print to equilibrium swollen state will increase with increasing concentrations of PEGDA, as seen in Figure 2. Thus, the change in size over the designed dimensions will be larger at higher PEGDA concentrations.

291 Extruded features will increase in size post swelling as described above. The cantilevers of the 292 printed MAP will therefore be larger than their CAD design dimensions. The microscopic 293 dimensional change of the printed samples is determined by making CAD designs with rectangular 294 indentations and protrusions (Electronic Supporting Information, Figure S2). The feature widths 295 are measured immediately after printing, as well as after swelling to equilibrium. Measured 296 dimensions are compared to the original CAD dimensions. Figure 3 compares the CAD design to 297 the initially printed dimensions and the final post-swelling dimensions. For both PEGDA 298 concentrations, protrusions exhibit less deviation from nominally designed dimensions to post299 swelling than indentations. MAP designs are therefore largely constructed as protrusions with 300 regards to cantilevers and well boundaries to ensure stability. Protrusion-based designs such as the 301 MINIMAP and LOWSTRESSMAP further benefit from using less material, thus easing the post302 manufacture washing procedure.

303 Indentations in selected structures of the LOWSTRESSMAP function are chosen as optical 304 markers since indentations are easier to visualize by microscopy than extrusions. In general, the 305 relative precision is higher for larger structures than for smaller structures at both PEGDA 

such as optical markers and mechanical cues to ensure manufacturability.
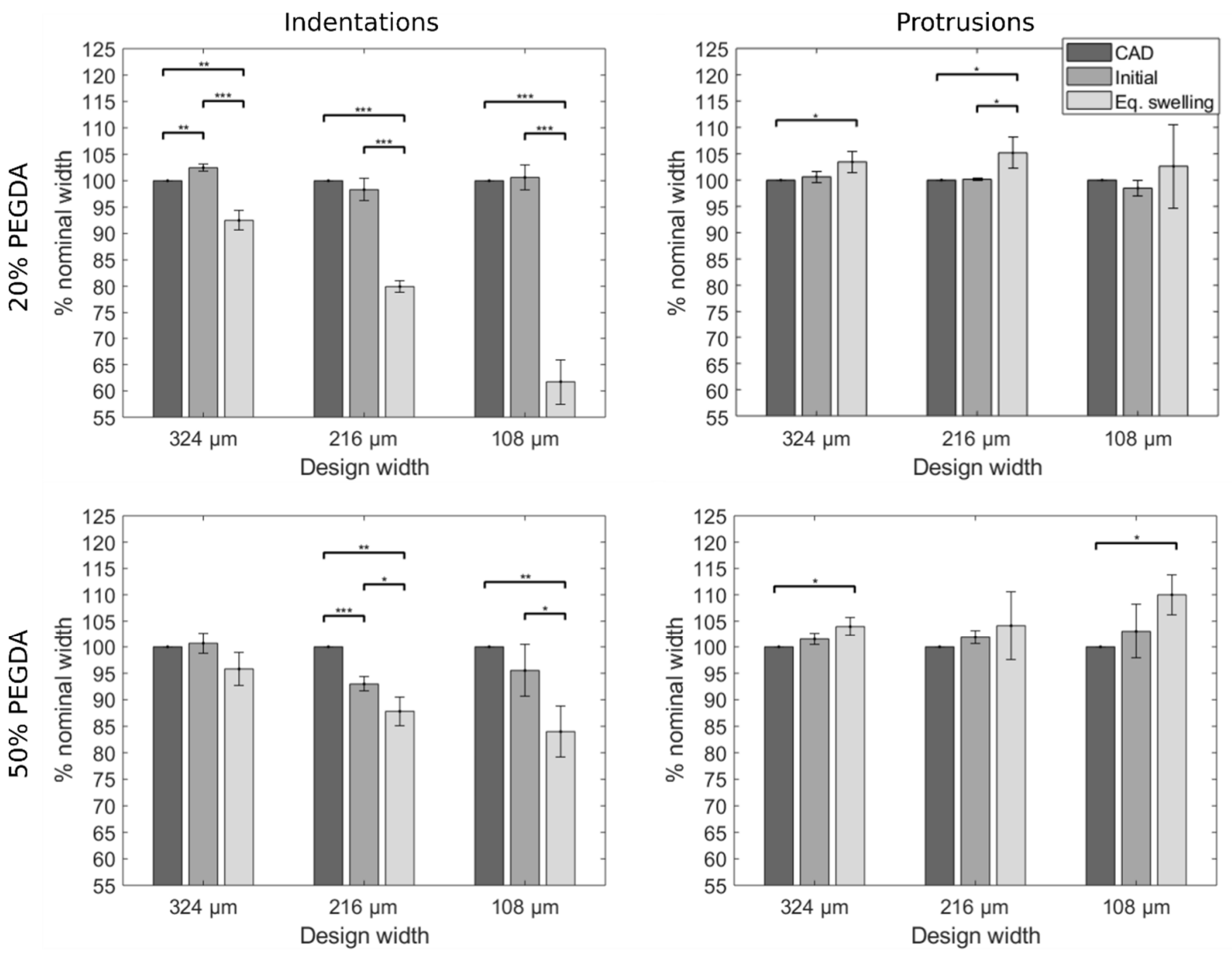

309 Figure 3. Measured dimensional change of the initial printed width and the equilibrium swelling

310 width of rectangular indentations and protrusions, relative to the nominal width of the CAD design.

311 Nominal widths range from $108 \mu \mathrm{m}$ to $324 \mu \mathrm{m}$, and the designs are printed in 20\% PEGDA and $31250 \%$ PEGDA. Error bars show the standard deviation $(\mathrm{n}=3) .{ }^{*} \mathrm{p}<0.05 * * \mathrm{p}<0.01 \quad * * * \mathrm{p}<0.001$.

\section{Controlling Cantilever Stiffness by Design and Print Composition.}

315 Quantitative readout of the MTS contraction force depends on knowledge of the mechanical 316 properties of the cantilevers on which the MTS are anchored. The cantilever stiffness depends 
strongly on its dimensions and can therefore easily be modified by design. The moment of inertia and thereby the stiffness of cantilevers with a circular cross-sectional area is predicted to depend on the fourth power of cantilever diameter as described by Eq. (4). The stiffness of $850 \mu \mathrm{m}$ long circular 3D printed cantilevers with diameters of $100 \mu \mathrm{m}, 200 \mu \mathrm{m}$, and $300 \mu \mathrm{m}$ is determined directly by measuring the force needed to deflect the cantilevers by a fixed distance $(220 \mu \mathrm{m})$. The stiffness of cantilevers in 20\% PEGDA is $0.07 \pm 0.006 \mathrm{~N} / \mathrm{m}$ (mean $\pm \mathrm{SD}$ ) for a nominal diameter of $100 \mu \mathrm{m}, 0.3 \pm 0.08 \mathrm{~N} / \mathrm{m}$ at $200 \mu \mathrm{m}$ diameter, and $2.4 \pm 0.3 \mathrm{~N} / \mathrm{m}$ at $300 \mu \mathrm{m}$ diameter. A similar

324 correlation is observed for cantilevers in 50\% PEGDA with a measured stiffness of $0.16 \pm 0.04$ $325 \mathrm{~N} / \mathrm{m}$ for a nominal diameter of $100 \mu \mathrm{m}, 3.05 \pm 0.35 \mathrm{~N} / \mathrm{m}$ at $200 \mu \mathrm{m}$ nominal diameter, and $19.2 \pm$ $3260.66 \mathrm{~N} / \mathrm{m}$ at $300 \mu \mathrm{m}$ nominal diameter. Figure 4 illustrates that cantilever stiffnesses covering 327 almost 3 orders of magnitude are accessible by varying the print design and the PEGDA 328 composition. As a lower bound on the available dimensions, we found that the aspect ratio of 100 $\mu \mathrm{m}$ diameter cantilevers is too high to be stably produced in 20\% PEGDA, whereas the $100 \mu \mathrm{m}$ cantilevers in 50\% PEGDA are robustly printed due to the higher cross-linking density. Even lower 331 stiffnesses can be achieved by using longer cantilever designs, since their stiffness scales with the 332 negative third power of their length (see Eq. (3)). Contractile cells adapt their cytoskeleton to form 333 an elongated structure depending on the mechanical influence provided by the cantilevers. The 334 optimal stiffness for robust formation of contractile tissue will depend on the specific cell line. It 335 is important to match the cantilever stiffness to the contractile strength of the cells to avoid tissue 336 necking and subsequent breaking. ${ }^{31,32}$ 


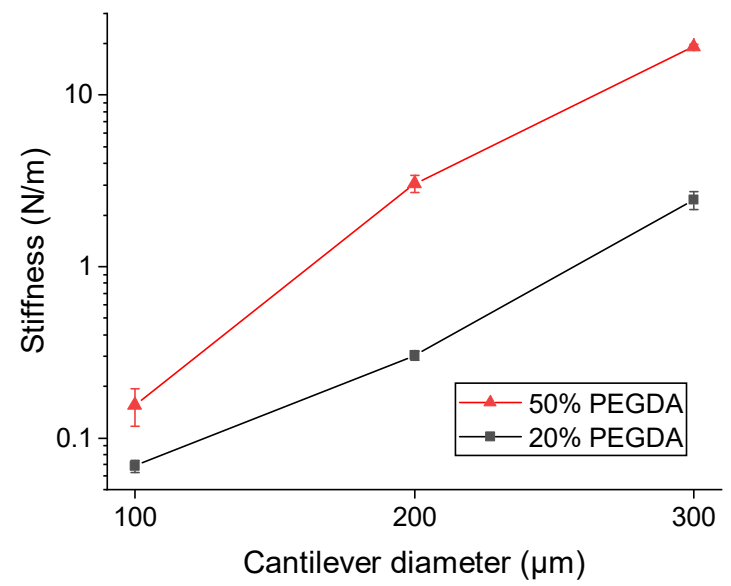

339 Figure 4. Cantilever stiffness dependence on the design diameter for $850 \mu \mathrm{m}$ long circular 340 cantilevers printed in 20\% PEGDA or 50\% PEGDA. Error bars show the standard deviations $(\mathrm{n}=$ $3415)$.

342 Varying the PEGDA concentration or the cantilever diameter changes the cantilever stiffness 343 and thus the force needed to deflect it. Using the mouse myoblasts $\mathrm{C} 2 \mathrm{C} 12$ cell line, we show a 344 strong correlation between cantilever stiffness and the ability of the tissues to deflect the 345 cantilevers. Figure 5 shows that stiffnesses up to $0.3 \mathrm{~N} / \mathrm{m}$ (compare with Figure 4 ) allow the formed 346 tissues to deflect the cantilevers with larger deflection observed at lower stiffness. The tissues exert 347 a force of $38 \pm 7 \mu \mathrm{N}($ mean $\pm \mathrm{SD}, \mathrm{n}=5)$ calculated from the deflection of the cantilevers seen in side 348 view (Figure 5) and the measured cantilever stiffness (Figure 4). 


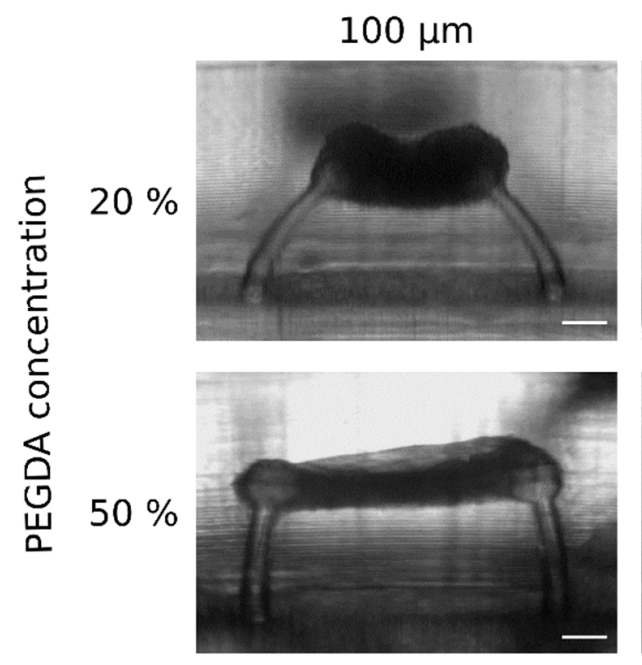

\section{Cantilever diameter}
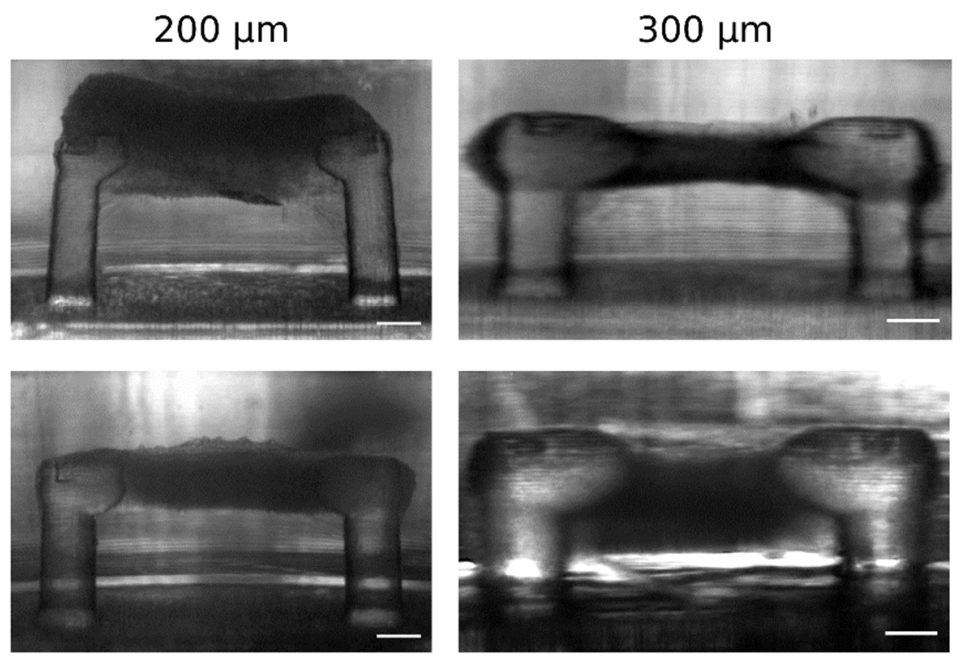

350 Figure 5. Deflection of cantilevers with varying diameter and PEGDA concentration. All

351 cantilevers are of equal height and the formed tissues consist of an equal number of cells. A strong

352 correlation between cantilever stiffness and the ability of the mouse myoblast tissue to deflect the

353 cantilevers is observed. Cantilever deflection is seen at both concentrations for cantilevers of 100

$354 \mu \mathrm{m}$ diameter and for $20 \%$ PEGDA $200 \mu \mathrm{m}$ diameter. No deflection is observed for the remaining cantilevers. Scale bars $200 \mu \mathrm{m}$.

\section{Formation of Muscle Tissue Strips.}

$358 \mathrm{C} 2 \mathrm{C} 12$ mouse myoblasts are cast at $10 \times 10^{6}$ cells $/ \mathrm{mL}$ in a fibrin/Matrigel matrix in the three 359 different MAPs. C2C12 cells will start to differentiate when they are in close proximity to each 360 other. $^{40}$ Upon differentiation, the myoblasts fuse and form myotubes. Elongation of the cells is a 361 sign of differentiation and shows alignment of the sarcomeres responsible for cell contraction. ${ }^{41}$

362 When the sarcomeres align, the cells can exert more force in the direction of the elongation. As

363 the cell laden fibrin matrix is embedded around the cantilevers, the cells' contraction of the matrix 364 is restricted by the cantilevers causing them to form an elongated structure and eventually an MTS. 
The stiffness of the cantilevers will continue to provide an opposing force when the cells are contracting, which is believed to aid the differentiation of the myoblasts into muscle cells. ${ }^{9,42}$ After

$36724 \mathrm{~h}$ of culture, the cells have started to contract the fibrin matrix and form a tissue surrounding 368 the two cantilevers (Figure 6). Two days after seeding, well-defined tissues are seen in all designs.

a)

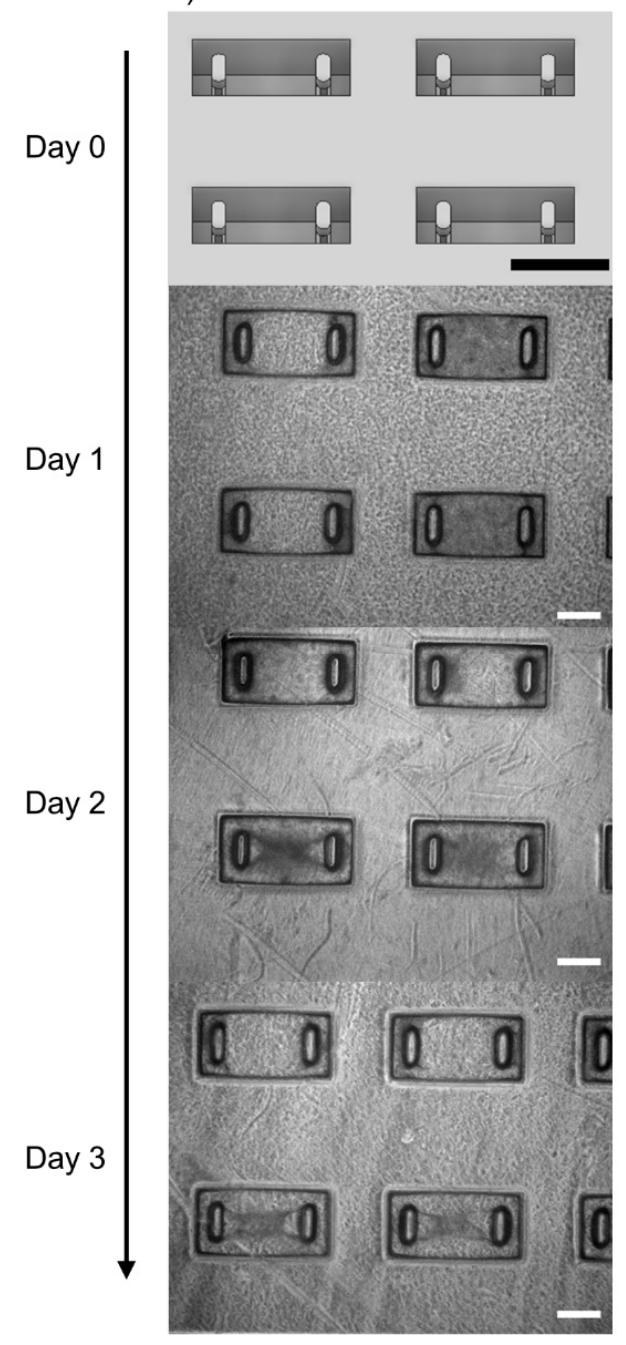

b)

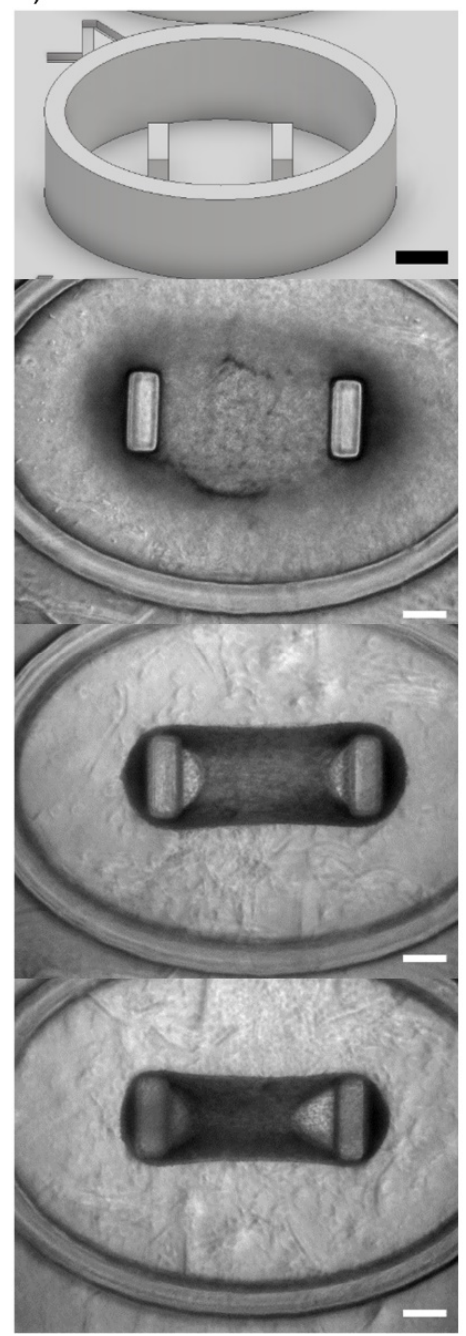

c)

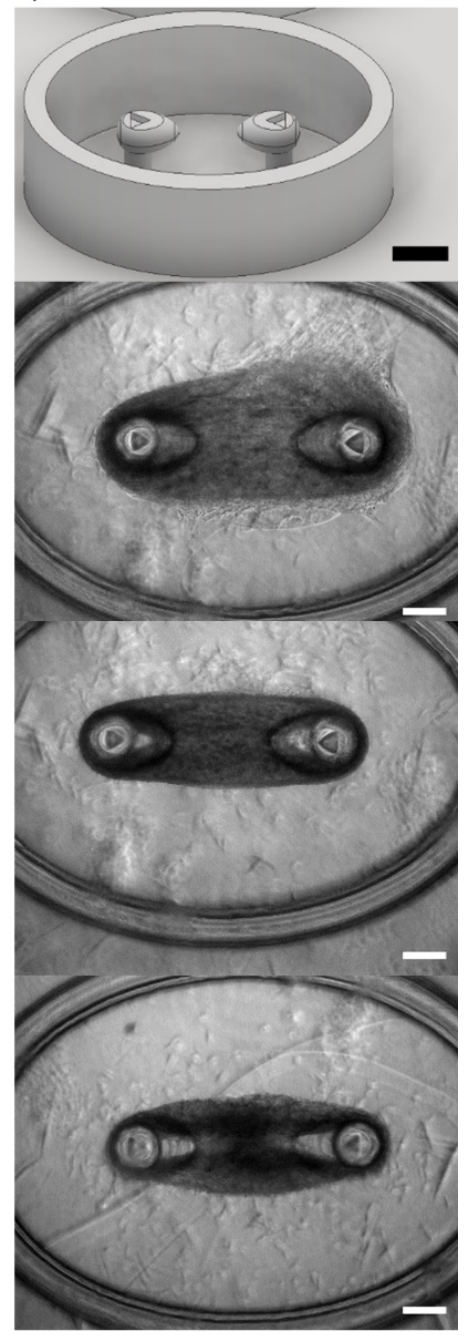

370 Figure 6. Tissue formation is observed over 4 days from cell loading into (a) MICROMAPs, (b)

371 MINIMAPs, and (c) LOWSTRESSMAPs, until compacted tissues are observed at day 3. White

372 scale bars $250 \mu \mathrm{m}$. Black scale bars $500 \mu \mathrm{m}$. 
374 In the MICROMAP, the formed tissue is surrounded by excess cells captured in the matrix 375 without contributing to the tissue formation (Figure $7 \mathrm{a}, \mathrm{b}$ ). The MICROMAP format requires fewer 376 cells per well due to the small well size, but requires a highly inefficient cell seeding method with 377 a lot of lost cells. In both the MICROMAP and MINIMAP, tissues are at risk of thinning and 378 ultimately breaking due to necking as seen in Figure 7 ( $b$ and d) marked with yellow dashed lines. 379 Necking is known to cause engineered tissues to fracture regardless of cell type and poses a serious 380 challenge in tissue engineering. ${ }^{25,31,32}$ Circular cantilevers provide an advantage over rectangular 381 cantilevers by not introducing the same degree of stress concentrations around the corners. This 382 reduces the risk of the thinning and ultimately breaking of the tissue that is seen in the 383 MICROMAP and MINIMAP tissues (Figure 6). Tissues created in our LOWSTRESSMAP design 384 using circular cantilevers with soft-edged biomechanical cues show no thinning around the 385 cantilevers at day 3 of culture. This MTS also exhibit a more defined tissue formation as seen in 386 Figure $6 \mathrm{c}$ and Figure $7(\mathrm{e}, \mathrm{f})$. All engineered tissues show a high cell viability and a tight cellular 387 structure with aligned cells (Figure $7(\mathrm{a}, \mathrm{c}, \mathrm{e})$ ). 


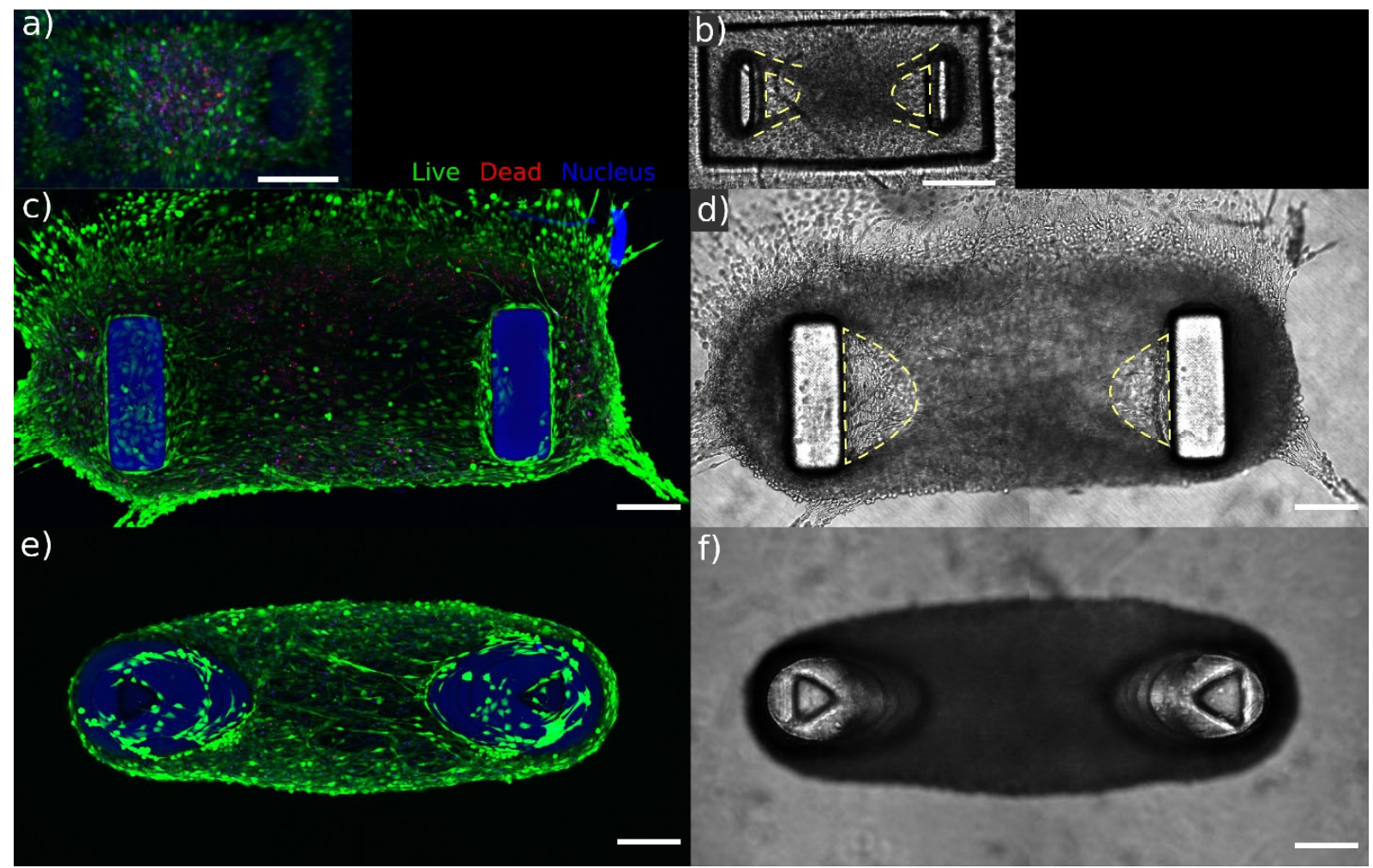

Figure 7. Optical micrographs of $\mathrm{C} 2 \mathrm{C} 12$ microtissues cultured for 3 days in MICROMAP (a and

390 b), MINIMAP (c and d) and LOWSTRESSMAP (e and f) designs. All seedings use C12C12 at $39110 \times 10^{6}$ cells $/ \mathrm{mL}$ in a $10 \mathrm{mg} / \mathrm{mL}$ fibrin gel with $20 \% \mathrm{v} / \mathrm{v}$ Matrigel. (a, c, e) Maximum intensity 392 projections of confocal fluorescence stacks of cells stained for live cells (green, calcein AM), dead 393 cells (red, propidium iodide), and nuclei (blue, Hoechst 33450). The printed cantilevers are also 394 seen in the blue channel due to autofluorescence of PEGDA. (b, d, f) Maximum intensity 395 projections of confocal bright field stacks. Yellow dashed lines indicate the areas where the tissues 396 are thinning from the stress induced by the edge of the cantilevers. Scale bars $200 \mu \mathrm{m}$.

398 Cryosectioned slices of the MINIMAP and LOWSTRESSMAP tissues show that the tissue 399 wraps around the cantilevers at the top so that these are fully surrounded by the tissues formed, as 400 required for optimal force transmission (Figure 8a,b). The tissue in the MINIMAP design fully Page 22 of 34 
401 enclose the cantilever ends and substantial parts of the cantilever length, which does not allow for 402 a well-defined attachment point as required in the Euler-Bernoulli theory for calculating the 403 contraction force (Figure 8a). In contrast, the mechanical cue added at the top of the circular 404 cantilevers in the LOWSTRESSMAP design causes less necking and better confinement of the 405 tissue near the free cantilever end (Figure 8b). Figure $8 \mathrm{c}$ shows that the cells in the 406 LOWSTRESSMAP design are aligned in the direction of the opposing force acting on the tissue 407 from the cantilever. Cells are multinucleated suggesting that the myoblasts have fused to form 408 myotubes. Introducing a biomechanical cue at the top of the cantilever makes the tissue form 409 uniformly around the cantilever (Figure 8b). The alignment and uniformness of the MTS indicate 410 that all cells experience the same opposing force and develop uniformly within the tissue. 

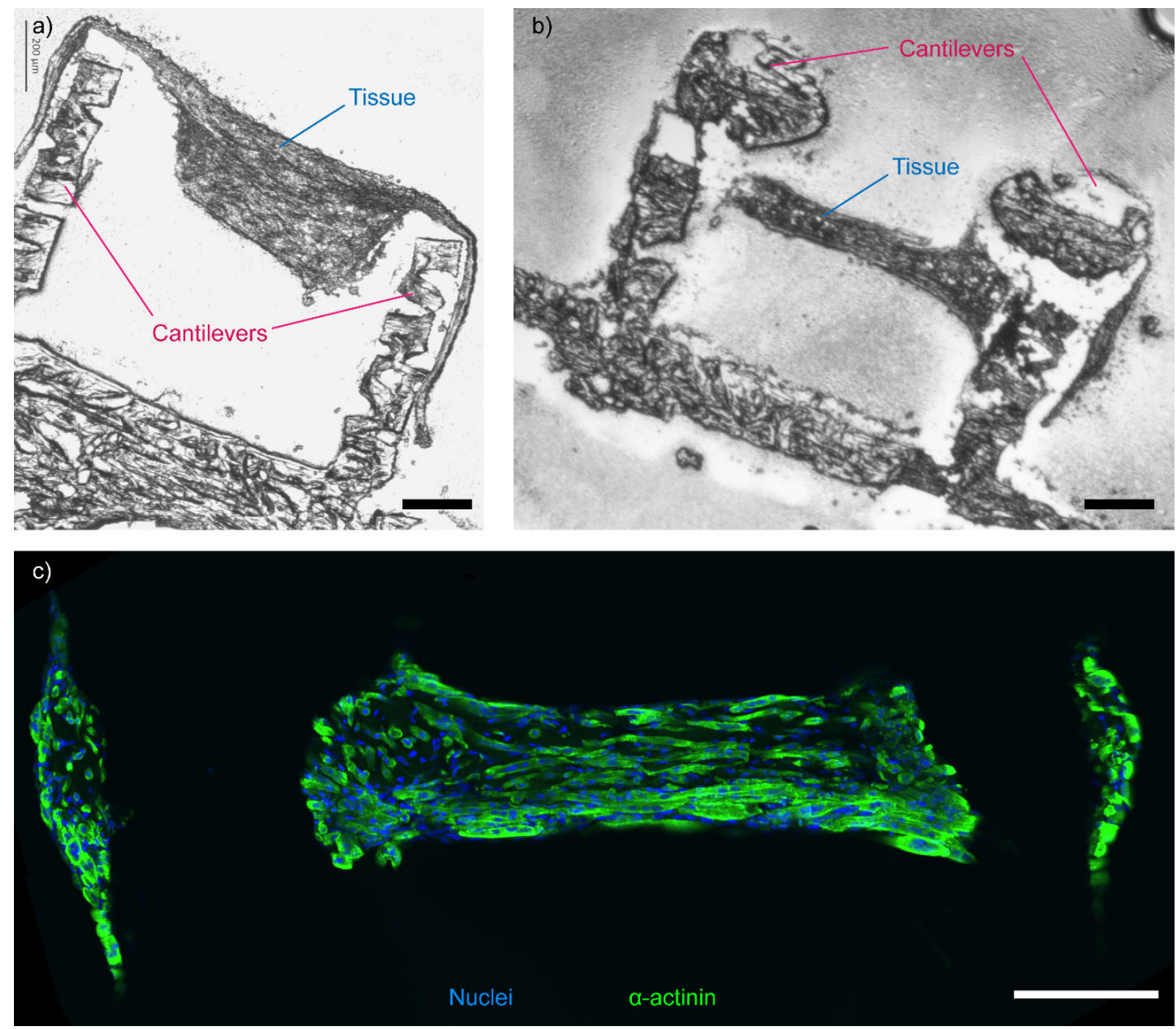

412 Figure 8. Brightfield micrographs of (a) MINIMAP and (b) LOWSTRESSMAP designs with

$413 \mathrm{C} 2 \mathrm{C} 12$ muscle tissue strips after fixation and cryosectioning (20 $\mu \mathrm{m}$ thick slice). (c) Spinning disc

414 confocal image of the LOWSTRESSMAP muscle tissue strip seen in (b) stained for $\alpha$-actinin

415 (green) and nuclei (blue). Scale bars: $200 \mu \mathrm{m}$.

417 As discussed, the new LOWSTRESSMAP design includes a visually distinct marker on top of 418 each cantilever. The marker is seen as a triangle in Figure $6 \mathrm{c}$ and Figure $7 \mathrm{f}$. When tissues form 
around the cantilever at the cue on top of the cantilevers, the height of tissue attachment is welldefined. This enables reliable calculation of the contractile force based on cantilever stiffness and deflection. The time-dependent cantilever deflection can be determined by optical tracking of the incorporated optical markers (Electronic Supporting Information, Video V1 and V2), thus enabling calculation of the force exerted by the cells in the engineered muscle tissue strip.

\section{CONCLUSIONS}

Our results show that high-resolution stereolithographic 3D printing of PEGDA hydrogels can mass-produce micromechanical objects, such as cantilevers, with high precision and with high accuracy. High accuracy is achieved by characterizing and accounting for post-printing swelling properties of hydrogels in the print design and in the choice of printing solution composition. Precise and accurate micromanufacturing enables fast and robust fabrication of cell seeding platforms for use in microtissue engineering, in a format that can be upscaled for commercial production. The cantilever stiffness is easily controlled by changing its design, which makes the platform suitable for various cell types with different contractile properties. The use of circular cylindrical cantilevers with an integrated stress-reducing biomechanical cue at their ends results in well defined muscle tissue strips without observable necking. Tissues are consistently formed at the bottom of the biomechanical cue, thus fixing the height of attachment on the cantilever. This is in contrast to the extended and variable length of attachment observed on rectangular cantilevers. A consistent and short length of tissue-cantilever attachment is key to subsequent reliable force readout, as the underlying Euler-Bernoulli theory requires a single well-defined point of actuation to translate observed cantilever deflection to exerted tissue force. 


\section{ASSOCIATED CONTENT}

Supporting Information. Optical micrographs of the experimental stiffness measurement of 3D printed cantilever structures. Drawing of the test structures used for assessing dimensional changes. The material is available free of charge via the Internet at http://pubs.acs.org.

\section{ACKNOWLEDGMENT}

We acknowledge financial support from Innovation Fund Denmark (industrial PhD grant 518900149B) and EUREKA Eurostars (CARDIOCONTRACT grant 01032018).

\section{REFERENCES}

(1) Kolesky, D. B.; Truby, R. L.; Gladman, A. S.; Busbee, T. A.; Homan, K. A.; Lewis, J. A. 3D Bioprinting of Vascularized, Heterogeneous Cell-Laden Tissue Constructs. Adv. Mater. 2014, 26 (19), 3124-3130. https://doi.org/10.1002/adma.201305506.

(2) Zhang, R.; Larsen, N. B. Stereolithographic Hydrogel Printing of 3D Culture Chips with Biofunctionalized Complex 3D Perfusion Networks. Lab Chip 2017, 17 (24), 4273-4282. https://doi.org/10.1039/C7LC00926G.

(3) Larsen, E. K. U.; Larsen, N. B. One-Step Polymer Surface Modification for Minimizing Drug, Protein, and DNA Adsorption in Microanalytical Systems. Lab Chip 2013, 13 (4), 669-675. https://doi.org/10.1039/c2lc40750g.

(4) Larsen, E. K. U.; Mikkelsen, M. B. L.; Larsen, N. B. Facile Photoimmobilization of Proteins onto Low-Binding PEG-Coated Polymer Surfaces. Biomacromolecules 2014, 15 (3), 894- 
899. https://doi.org/10.1021/bm401745a.

(5) Ulmer, B. M.; Stoehr, A.; Schulze, M. L.; Patel, S.; Gucek, M.; Mannhardt, I.; Funcke, S.; Murphy, E.; Eschenhagen, T.; Hansen, A. Contractile Work Contributes to Maturation of Energy Metabolism in HiPSC-Derived Cardiomyocytes. Stem Cell Reports 2018, 10 (3), 834-847. https://doi.org/10.1016/j.stemcr.2018.01.039.

(6) Vandenburgh, H.; Shansky, J.; Benesch-Lee, F.; Barbata, V.; Reid, J.; Thorrez, L.; Valentini, R.; Crawford, G. Drug-Screening Platform Based on the Contractility of TissueEngineered Muscle. Muscle Nerve 2008, $37 \quad$ (4), 438-447. https://doi.org/10.1002/mus.20931.

(7) Lux, M.; Andrée, B.; Horvath, T.; Nosko, A.; Manikowski, D.; Hilfiker-Kleiner, D.; Haverich, A.; Hilfiker, A. In Vitro Maturation of Large-Scale Cardiac Patches Based on a Perfusable Starter Matrix by Cyclic Mechanical Stimulation. Acta Biomater. 2016, 30, 177187. https://doi.org/10.1016/j.actbio.2015.11.006.

(8) Gaio, N.; van Meer, B.; Quirós Solano, W.; Bergers, L.; van de Stolpe, A.; Mummery, C.; Sarro, P.; Dekker, R. Cytostretch, an Organ-on-Chip Platform. Micromachines 2016, 7 (7), 120. https://doi.org/10.3390/mi7070120.

(9) Liao, I.-C.; Liu, J. B.; Bursac, N.; Leong, K. W. Effect of Electromechanical Stimulation on the Maturation of Myotubes on Aligned Electrospun Fibers. Cell. Mol. Bioeng. 2008, 1 (2-3), 133-145. https://doi.org/10.1007/s12195-008-0021-y.

(10) Li, N.; Schwartz, M.; Ionescu-Zanetti, C. PDMS Compound Adsorption in Context. J. Biomol. Screen. 2009, 14 (2), 194-202. https://doi.org/10.1177/1087057108327326. 
(11) Cvetkovic, C.; Raman, R.; Chan, V.; Williams, B. J.; Tolish, M.; Bajaj, P.; Sakar, M. S.; Asada, H. H.; Saif, M. T. A.; Bashir, R. Three-Dimensionally Printed Biological Machines Powered by Skeletal Muscle. Proc. Natl. Acad. Sci. U. S. A. 2014, 111 (28), 10125-10130. https://doi.org/10.1073/pnas.1401577111.

(12) Kensah, G.; Roa Lara, A.; Dahlmann, J.; Zweigerdt, R.; Schwanke, K.; Hegermann, J.; Skvorc, D.; Gawol, A.; Azizian, A.; Wagner, S.; Maier, L. S.; Krause, A.; Dräger, G.; Ochs, M.; Haverich, A.; Gruh, I.; Martin, U. Murine and Human Pluripotent Stem Cell-Derived Cardiac Bodies Form Contractile Myocardial Tissue in Vitro. Eur. Heart J. 2013, 34 (15), 1134-1146. https://doi.org/10.1093/eurheartj/ehs349.

(13) Mills, R. J.; Parker, B. L.; Monnot, P.; Needham, E. .; Vivien, C. J.; Ferguson, C.; Parton, R. G.; James, D. E.; Porrello, E. R.; Hudson, J. E. Development of a Human Skeletal Micro Muscle Platform with Pacing Capabilities. Biomaterials 2019, 198, 217-227. https://doi.org/10.1016/j.biomaterials.2018.11.030.

(14) Sidorov, V. Y.; Samson, P. C.; Sidorova, T. N.; Davidson, J. M.; Lim, C. C.; Wikswo, J. P. I-Wire Heart-on-a-Chip I: Three-Dimensional Cardiac Tissue Constructs for Physiology and Pharmacology. Acta Biomater. 2017, 48, 68-78. https://doi.org/10.1016/j.actbio.2016.11.009.

(15) Schroer, A. K.; Shotwell, M. S.; Sidorov, V. Y.; Wikswo, J. P.; Merryman, W. D. I-Wire Heart-on-a-Chip II: Biomechanical Analysis of Contractile, Three-Dimensional Cardiomyocyte Tissue Constructs. Acta Biomater. 2017, 48, 79-87. https://doi.org/10.1016/j.actbio.2016.11.010.

(16) Lemoine, M. D.; Krause, T.; Koivumäki, J. T.; Prondzynski, M.; Schulze, M. L.; 
Girdauskas, E.; Willems, S.; Hansen, A.; Eschenhagen, T.; Christ, T. Human Induced Pluripotent Stem Cell-Derived Engineered Heart Tissue as a Sensitive Test System for QT Prolongation and Arrhythmic Triggers. Circ. Arrhythmia Electrophysiol. 2018, 11 (7), e006035. https://doi.org/10.1161/CIRCEP.117.006035.

(17) Nugraha, B.; Buono, M. F.; von Boehmer, L.; Hoerstrup, S. P.; Emmert, M. Y. Human Cardiac Organoids for Disease Modeling. Clin. Pharmacol. Ther. 2019, 105 (1), 79-85. https://doi.org/10.1002/cpt.1286.

(18) Nawroth, J. C.; Scudder, L. L.; Halvorson, R. T.; Tresback, J.; Ferrier, J. P.; Sheehy, S. P.; Cho, A.; Kannan, S.; Sunyovszki, I.; Goss, J. A.; Campbell, P. H.; Parker, K. K. Automated Fabrication of Photopatterned Gelatin Hydrogels for Organ-on-Chips Applications. Biofabrication 2018, 10 (2), 025004. https://doi.org/10.1088/1758-5090/aa96de.

(19) Benam, K. H.; Dauth, S.; Hassell, B.; Herland, A.; Jain, A.; Jang, K.-J.; Karalis, K.; Kim, H. J.; MacQueen, L.; Mahmoodian, R.; Musah, S.; Torisawa, Y.-S.; van der Meer, A. D.; Villenave, R.; Yadid, M.; Parker, K. K.; Ingber, D. E. Engineered In Vitro Disease Models. Annu. Rev. Pathol. Mech. Dis. 2015, 10 (1), 195-262. https://doi.org/10.1146/annurevpathol-012414-040418.

(20) Marelli, M.; Gadhari, N.; Boero, G.; Chiquet, M.; Brugger, J. Cell Force Measurements in 3D Microfabricated Environments Based on Compliant Cantilevers. Lab Chip 2014, 14 (2), 286-293. https://doi.org/10.1039/C3LC51021B.

(21) Chan, V.; Jeong, J. H.; Bajaj, P.; Collens, M.; Saif, T.; Kong, H.; Bashir, R. Multi-Material Bio-Fabrication of Hydrogel Cantilevers and Actuators with Stereolithography. Lab Chip 2012, 12 (1), 88-98. https://doi.org/10.1039/C1LC20688E. 
(22) McCain, M. L.; Agarwal, A.; Nesmith, H. W.; Nesmith, A. P.; Parker, K. K. Micromolded Gelatin Hydrogels for Extended Culture of Engineered Cardiac Tissues. Biomaterials 2014, 35 (21), 5462-5471. https://doi.org/10.1016/j.biomaterials.2014.03.052.

(23) Mannhardt, I.; Breckwoldt, K.; Letuffe-Brenière, D.; Schaaf, S.; Schulz, H.; Neuber, C.; Benzin, A.; Werner, T.; Eder, A.; Schulze, T.; Klampe, B.; Christ, T.; Hirt, M. N.; Huebner, N.; Moretti, A.; Eschenhagen, T.; Hansen, A. Human Engineered Heart Tissue: Analysis of Contractile Force. Stem Cell Reports 2016, $7 \quad$ (1), 29-42. https://doi.org/10.1016/j.stemcr.2016.04.011.

(24) Legant, W. R.; Pathak, A.; Yang, M. T.; Deshpande, V. S.; McMeeking, R. M.; Chen, C. S. Microfabricated Tissue Gauges to Measure and Manipulate Forces from 3D Microtissues. Proc. Natl. Acad. Sci. U. S. A. 2009, $106 \quad$ (25), $10097-10102$. https://doi.org/10.1073/pnas.0900174106.

(25) Mills, R. J.; Titmarsh, D. M.; Koenig, X.; Parker, B. L.; Ryall, J. G.; Quaife-Ryan, G. A.; Voges, H. K.; Hodson, M. P.; Ferguson, C.; Drowley, L.; et al. Functional Screening in Human Cardiac Organoids Reveals a Metabolic Mechanism for Cardiomyocyte Cell Cycle Arrest. Proc. Natl. Acad. Sci. 2017, $114 \quad$ (40), E8372-E8381. https://doi.org/10.1073/pnas.1707316114.

(26) Ikeda, K.; Ito, A.; Imada, R.; Sato, M.; Kawabe, Y.; Kamihira, M. In Vitro Drug Testing Based on Contractile Activity of C2C12 Cells in an Epigenetic Drug Model. Sci. Rep. 2017, 7 (1), 44570. https://doi.org/10.1038/srep44570.

(27) Wanjare, M.; Huang, N. F. Regulation of the Microenvironment for Cardiac Tissue Engineering. Regen. Med. 2017, 12 (2), 187. https://doi.org/10.2217/RME-2016-0132. 
(28) Yang, C.; DelRio, F. W.; Ma, H.; Killaars, A. R.; Basta, L. P.; Kyburz, K. A.; Anseth, K. S. Spatially Patterned Matrix Elasticity Directs Stem Cell Fate. Proc. Natl. Acad. Sci. U. S. A. 2016, 113 (31), E4439-E4445. https://doi.org/10.1073/pnas.1609731113.

(29) Zhang, W.; Kong, C. W.; Tong, M. H.; Chooi, W. H.; Huang, N.; Li, R. A.; Chan, B. P. Maturation of Human Embryonic Stem Cell-Derived Cardiomyocytes (HESC-CMs) in 3D Collagen Matrix: Effects of Niche Cell Supplementation and Mechanical Stimulation. Acta Biomater. 2017, 49, 204-217. https://doi.org/10.1016/j.actbio.2016.11.058.

(30) Wang, Z.; Lee, S. J.; Cheng, H.-J.; Yoo, J. J.; Atala, A. 3D Bioprinted Functional and Contractile Cardiac Tissue Constructs. Acta Biomater. 2018, 70, 48-56. https://doi.org/10.1016/J.ACTBIO.2018.02.007.

(31) Wang, H.; Svoronos, A. A.; Boudou, T.; Sakar, M. S.; Schell, J. Y.; Morgan, J. R.; Chen, C. S.; Shenoy, V. B. Necking and Failure of Constrained 3D Microtissues Induced by Cellular Tension. Proc. Natl. Acad. Sci. 2013, $110 \quad$ (52), 20923-20928. https://doi.org/10.1073/pnas.1313662110.

(32) Boudou, T.; Legant, W. R.; Mu, A.; Borochin, M. A.; Thavandiran, N.; Radisic, M.; Zandstra, P. W.; Epstein, J. A.; Margulies, K. B.; Chen, C. S. A Microfabricated Platform to Measure and Manipulate the Mechanics of Engineered Cardiac Microtissues. Tissue Eng. Part A 2012, 18 (9-10), 910-919. https://doi.org/10.1089/ten.tea.2011.0341.

(33) Sakar, M. S.; Neal, D.; Boudou, T.; Borochin, M. A.; Li, Y.; Weiss, R.; Kamm, R. D.; Chen, C. S.; Asada, H. H. Formation and Optogenetic Control of Engineered 3D Skeletal Muscle Bioactuators. Lab Chip 2012, 12 (23), 4976-4985. https://doi.org/10.1039/c2lc40338b. 
(34) Schindelin, J.; Arganda-Carreras, I.; Frise, E.; Kaynig, V.; Longair, M.; Pietzsch, T.; Preibisch, S.; Rueden, C.; Saalfeld, S.; Schmid, B.; Tinevez, J.-Y.; White, D. J.; Hartenstein, V.; Eliceiri, K.; Tomancak, P.; Cardona, A. Fiji: An Open-Source Platform for BiologicalImage Analysis. Nat. Methods 2012, 9 (7), 676-682. https://doi.org/10.1038/nmeth.2019.

(35) Treloar, L. R. G. The Physics of Rubber Elasticity, 3rd ed.; Oxford University Press, 1975.

(36) Yoshida, N.; Yoshida, S.; Koishi, K.; Masuda, K.; Nabeshima, Y. Cell Heterogeneity upon Myogenic Differentiation: Down-Regulation of MyoD and Myf-5 Generates 'Reserve Cells.' J. Cell Sci. 1998, 111 (6), 769-779.

(37) Schaaf, S.; Eder, A.; Vollert, I.; Stöhr, A.; Hansen, A.; Eschenhagen, T. Generation of StripFormat Fibrin-Based Engineered Heart Tissue (EHT). In Methods in Molecular Biology; Radisic, M., Black III, L. D., Eds.; Humana Press: New York, 2014; Vol. 1181, pp 121129. https://doi.org/10.1007/978-1-4939-1047-2_11.

(38) Yamaguchi, T.; Sato, R.; Sawae, Y. Propagation of Fatigue Cracks in Friction of Brittle Hydrogels. Gels 2018, 4 (2), 53. https://doi.org/10.3390/gels4020053.

(39) Ehrenhofer, A.; Elstner, M.; Wallmersperger, T. Normalization of Hydrogel Swelling Behavior for Sensoric and Actuatoric Applications. Sens. Actuators, B 2018, 255, 13431353. https://doi.org/10.1016/j.snb.2017.08.120.

(40) Tanaka, K.; Sato, K.; Yoshida, T.; Fukuda, T.; Hanamura, K.; Kojima, N.; Shirao, T.; Yanagawa, T.; Watanabe, H. Evidence for Cell Density Affecting C2C12 Myogenesis: Possible Regulation of Myogenesis by Cell-Cell Communication. Muscle Nerve 2011, 44 (6), 968-977. https://doi.org/10.1002/mus.22224. 
(41) Ostrovidov, S.; Ahadian, S.; Ramon-Azcon, J.; Hosseini, V.; Fujie, T.; Parthiban, S. P.; Shiku, H.; Matsue, T.; Kaji, H.; Ramalingam, M.; Bae, H.; Khademhosseini, A. ThreeDimensional Co-Culture of C2C12/PC12 Cells Improves Skeletal Muscle Tissue Formation and Function. J. Tissue Eng. Regen. Med. 2017, 11 (2), 582-595. https://doi.org/10.1002/term.1956.

(42) Engler, A. J.; Griffin, M. A.; Sen, S.; Bönnemann, C. G.; Sweeney, H. L.; Discher, D. E. Myotubes Differentiate Optimally on Substrates with Tissue-like Stiffness: Pathological Implications for Soft or Stiff Microenvironments. J. Cell Biol. 2004, 166 (6), 877-887. https://doi.org/10.1083/jcb.200405004. 